\title{
The Effect of Social Capital and Human Capital on Performance Effectiveness of National Zakat Institutions in Indonesia, Surabaya, Headquarters Experiences
}

\author{
I.Qurratu'ain *, E.F. Cahyono, L.N. Rani, S.A. Rusmita \\ Universitas Airlangga \\ Surabaya, Indonesia
}

\begin{abstract}
The present article aims to find out the influence of social capital and human capital on performance effectiveness of Amil Zakat National Institutions in Surabaya. The method used in this research is quantitative multiple linear regression, and the data was taken from the questionnaires. This research was conducted in 2017 from four samples of Amil Zakat National Institutions namely Yatim Mandiri, Nurul Hayat, Infaq Lembaga Manajemen Infaq (LMI) dan Yayasan Dana Sosial Al Falah (YDSF). According to the results of the survey, it is observed that social capital and human capital are the significant influences of performance effectiveness on Amil Zakat National Institutions in Surabaya.
\end{abstract}

Keywords-Social Capital; Human Capital; Performance Effectiveness

\section{INTRODUCTION}

Indonesia as the country with the largest Muslim population in the world has zakat or 'purify' as the instrument of Islamic Economics that expected to solve income and wealth distribution problems effectively. In addition, zakat that means a form of alms-giving treated in Islam as a religious obligation or tax also a very reliable mechanism to overcome poverty that is a cultural problem in Indonesia.

There are two types of zakat institutions in Indonesia. The first type named Badan Amil Zakat (BAZNAS) which is a zakat management institution established by the government and the second one is Lembaga Amil Zakat (LAZ) that formed by non-government.

The Religion Minister of Indonesia issued a regulation regarding zakat institution standard, namely KMA No. 333 of 2015 on Guidelines for Giving Permit Establishment of Zakat Institutions (Pedoman Pemberian Izin Pembentukan Lembaga Amil Zakat). This regulatory is the first step to improve the effectiveness of zakat management performance and has been approved by the Minister of Religious Affairs of Indonesia on November 6, 2015 (Minister of Religious Affairs of Indonesia 2015). It regulates the types of LAZ and minimum fundraising requirements. For National institution, the minimum fund to be collected is IDR 50 billion. Meanwhile, The Province Zakat Institution is IDR 20 billion and District/City Zakat Institution is IDR 3 billion (Minister of Religious Affairs of Indonesia 2015).

One of the biggest problems of Zakat Institutions in Indonesia is the optimization of its potential. The potential of zakat in Indonesia in 2007 reached more than IDR 9 trillion per year, then increased to IDR 217 trillion in 2011 and IDR 422 trillion in 2016. However, the amount of zakat funds in 2016 is only $1 \%$ of its potential, which is around IDR 4.2 trillion based on databases owned by BAZNAS in 2016.

\section{LITERATURE REVIEW}

[1] identifies the possibilities that cause the lacking on zakat management, that are 1) ineffectiveness of zakat management organizations; 2) high administrative costs to manage the zakat; 3 ) ineffective information on the urgency of zakat; and 4) muzakki (the one who gives zakat) mistrust of Zakat Institutions. Based on the four inhibiting factors above, if we look more deeply it can be seen that points 3 and 4 are social capital problems while points 1 and 2 are the issues of human capital in Zakat Institutions.

The importance of economic or financial capital, social capital and human capital for finding an exit path of povertywhich zakat is the most ideal option, is a popular issue in the present time. Social capital plays a crucial role in facilitating adoption, and overcoming constraints of lack financial and human capital [2]. According to $\mathrm{x}$ on his research article, the benefit from social capital and its merit can be an affective help in achieving to human development in organizations. The term of "social capital" and "human capital" are considered as key elements in improving the assets of an organization, since both of that are sustainable competitive advantages and increases the employees' efficiency that leads to the higher level of organization's performance effectiveness [3]

Social capital is such an important asset as a resource owned by the community. This social capital gives strength and power in some social conditions in society. There are 3 main elements on social capital, as follows 1) trust; 2) network and; 3) norm [4]. It is said that social capital can improve economic performance by reducing transaction costs which is more effectively allocate resources to competitive advantage [5].

The definition of human capital is literally knowledge, expertise, ability and skill that qualify people as capital or company assets [6]. Human capital plays important role in people's development which is a strategic move in organizations by improving life and income, increasing knowledge, skill, and product capacities, economic growth and reducing poverty [3]. Nowadays, human capital is proved 
H2: human capital has a positive significant impact on performance effectiveness based on employees' perception.

H3: social capital and human capital have positive significant impact on performance effectiveness based on employees' perception simultaneously. that have complied the Zakat Institutions standard regulation of Minister of Religious Affairs of Indonesia, namely KMA No. 333 of 2015 on Guidelines for Giving Permit Establishment of Amil Zakat Institute. These four institutions are Yatim Mandiri, Nurul Hayat, Lembaga Manajemen Infaq (LMI) and Yayasan Dana Sosial Al Falah (YDSF). Based on this information, we decided that the four institutions mentioned above are the most suitable zakat institutions to be representative in this research.

In the present paper, we explore about the relationships between social capital, human capital and performance effectiveness on National Zakat Institutions based on employees' perception.

\section{MethodolOGY}

\section{A. Data}

This study uses a quantitative approach by conducting two sources of data: primary and secondary data. Primary data is acquired through questionnaire survey and short interview. Both the questionnaire and interview questions are asked to all employees (amil) of our selected institutions that have been registered to a regulation named KMA no. 333 of 2015. These institutions are Yatim Mandiri, Nurul Hayat, Lembaga Manajemen Infaq (LMI) and Yayasan Dana Sosial Al Falah (YDSF).

The questionnaire is designed by using Likert scale. It includes 57 items that are scored on either a 5 point scale $(5$, strongly agree; 4, agree; 3 , neither agree nor disagree; 2, disagree; and 1, strongly disagree). The reliability and validity of the questionnaire have been established. However, the secondary data is gathered from internal data with relevance to the problems studied.

For measuring the performance effectiveness, we use the following variables:

1. Social capital (X1): Trust, network, norm.

2. Human Capital (X2): Knowledge, ability, skill.

3. Performance effectiveness (Y): Goal approach, system theory approach, effectiveness criteria.

\section{B. Hypothesis}

In this article, we attempted to make hypothesis as temporary answer to the research to be empirically tested as below:

H1: social capital has a positive significant impact on performance effectiveness based on employees' perception.

\section{Data analysis method}

There is a five-step analysis conducted in this research, namely descriptive statics, quality test instrument (validity and reliability testing), classical assumption test (normality test, linearity test, multicollinearity test, and heteroscedasticity test), data analysis (multiple regression analysis, F test, t-test, R2 test), and correlation test between dimensions. We used SPSS (Statistical Product for Service Solution) version 21 for software assistants as we analyzed the data.

\section{RESULTS AND DISCUSSION}

A. Validity and reliability tests

Before performing the test, questionnaire as an instrument must pass its validity and reliability tests. After testing the validity of the questionnaire, we find out that all questionnaire indicators are valid and reliable.

B. The classical assumption tests

Before testing the hypothesis, the first thing to do is testing the classical assumption tests. These tests used to determine the relationship between variables, including normality test, linearity test, multicollinearity test, and heteroscedasticity test. In this research, we find out that these classical assumption are true, which is the regression results produce the best estimates.

C. Multiple linear regression

This table below is the following output of the regression test:

Table 1. Regression equation result.

\begin{tabular}{lllll}
\multirow{2}{*}{ Model } & \multicolumn{2}{l}{$\begin{array}{l}\text { Unstandardized } \\
\text { Coefficients }\end{array}$} & & \multirow{2}{*}{ Sig. } \\
\cline { 2 - 3 } & $\mathrm{B}$ & Std. Error & & \\
\hline (Constant) & 20.666 & 3.069 & 6.734 & 0.000 \\
Social Capital & 0.117 & 0.041 & 2.823 & 0.005 \\
Human Capital & 0.225 & 0.032 & 6.977 & 0.000 \\
\hline
\end{tabular}

a. Dependent Variable: Performance Effectiveness

Based on the test results, the equation model in this study are as follows:

$\mathrm{Y}=20.666+0.177 \mathrm{X} 1+0.225 \mathrm{X} 2+6,734$

The equation can be explained as follows:

a. The constant value of 20.666 indicates that when social capital and human capital are zero (0), then the performance effectiveness value at National Institute of Amil Zakat in Surabaya is equal to 20.666. 
formal procedures in the form of policies and bureaucracies

b. The social capital regression coefficient of 0.117 has the same direction as the coefficient of performance effectiveness. This means that each increase of one unit social capital will causes an increase in the effectiveness of performance by 0.117 , vice versa.

c. The human capital regression coefficient of 0.225 has the same direction as the coefficient of performance effectiveness. This means that each increase of one unit social capital will causes an increase in the effectiveness of performance by 0.225 , vice versa.

D. Coefficient of determination

The coefficient of determination is used to find out the shifting percentage of dependent variable (Y) that is caused by independent variables $(\mathrm{X})$. After we run the test, the coefficient of determination is as follows:

Table 2. Coefficient of determination test ${ }^{\mathrm{b}}$.

\begin{tabular}{lllll} 
Model & R & R Square & $\begin{array}{l}\text { Adjusted } \\
\text { Square }\end{array}$ & $\begin{array}{l}\text { Rtd. } \\
\text { Error of } \\
\text { the } \\
\text { Estimate }\end{array}$ \\
\hline 1 & $0.574 a$ & 0.329 & 0.322 & 3.761 \\
\hline
\end{tabular}

Based on the SPSS test results as shown on the previous table, it can be seen that the effect of independent variables on dependent variables are expressed by the value of coefficient of determination (R2) of 0.329 or $32.9 \%$. It can be concluded that the changes of performance effects can be influenced by social capital and human capital by $32.9 \%$, while the remaining $67.1 \%$ is influenced by other variables outside the model on this study.

E. Hypothesis verification by t-test result

The results of $t$ arithmetic for the independent variables are shown on the following table:

Table 3. T-test result.

\begin{tabular}{lll}
\hline Model & $\mathrm{t}$ & Sig. \\
\hline (Constant) & 6.734 & 0.000 \\
Social Capital & 2.823 & 0.005 \\
Human Capital & 6.977 & 0.000
\end{tabular}

$F$. The relationship of human capital and performance effectiveness

As we can see in the table above, the significance value of social capital by 0.005 is equal to the predetermined degree of error, which is 0.005 . It means Hypothesis 1 is accepted.

The existence of trust in an organization will avoid conflicts and issues at work, whether on individual, team, or corporate level. Trust can also under-lie the relationships within colleagues, subordinates, and superiors. If trust is well established, the effectiveness of the company's performance will increase.

In addition to trust, the aspect raised from this social capital variable is the network. Modern organizations today have that may have been too complicated. Therefore many people are beginning to ignore this formal procedure and prefer to speak directly to other people they know. Asking for help from trusted friends, family or acquaintances is much easier than dealing with bureaucracy. In addition, it is also providing results that are more satisfying faster. In the context of the National Zakat Institutions, employees who have external networks, for example in the collection of zakat they have a family that potentially become muzakki will certainly produce more effective and efficient work. It is because the employee is familiar with both members of his family so they can pass through some formal bureaucracy.

And then there is the norm. As it has been known, one of essential keys of an organization to success is determined by its human capabilities that require knowledge, skills, tenacity, and expertise. To get a human who has the knowledge, skill, tenacity, and expertise is necessary to have discipline in doing activities. Work discipline is the will and willingness of the employees to obey and comply with all applicable rules and regulations, or norms, both written and unwritten. For the company, employees' discipline is an important element in achieving the goal. Compliance and adherence attitudes on achieving organization's goals if supported by high discipline of its employees will obtain optimal results of success. So then the performance effectiveness can also be achieved well.

$G$. The Relationship of human capital and performance effectiveness

Hypothesis 2 is also accepted. It is approved as the significance value of social capital by 0.000 is smaller than the predetermined degree of error, which is 0.005 .

The first component of human capital variable in this study is knowledge. It is said that knowledge can be used to develop precious competitiveness that are valuable, scarce, and difficult to follow by competitors. An organization or a company could have excellent competitiveness if it has good continuous innovations. The good innovation is determined by how well the company has reserves of knowledge through human capital on improving its performance effectiveness.

In addition to knowledge, we use ability as the component of human capital. The ability of an employee is a manifestation of the knowledge and skills possessed. The ability itself is composed of two things, namely intellectual ability and physical abilities. Intellectual ability is needed to perform mental activities, such as thinking, reasoning, problems solving, and working under pressure. The physical ability demands stamina, strength, dexterity, endurance, and employee skills. The higher the ability level of employee, the higher the productivity achieved. Thus automatically the performance effectiveness will increase and the company's goals will be achieved.

The next component is skill. The developments of talent, creativity, innovation, and work skills are usually grown in the educational environment and developed in the process of work training. It emphasizes professional ability, which will increase employee productivity. As employees' productivity 
using five general categories of effectiveness criteria according to Gibson. The five general categories of effectiveness criteria are production, efficiency, satisfaction, adaptability and development [8]. Gibson further states that the main criterion of corporate effectiveness is the company's survival in its surrounding environment. This effectiveness criterion is a time dimension where in the short term effectiveness is measured by production, efficiency and satisfaction. When these three criteria are met well, then the next criterion, namely development and adaptation reflecting the effectiveness of the medium term can be achieved. After achieving the criteria of development and adaptation, in the long term the survival of the company will be achieved.

\section{CONCLUSION}

Our empirical analysis showed that the social capital and human capital have influence significant on performance effectiveness of National Institute of Amil Zakat partially and simultaneously. Moreover, the results of this study also provide that the dependent variables are notably affecting institutions' performance effectiveness by the sign of the correlations that showed positively correlated.

That is to say, all employees agree that the organization of zakat's performance effectiveness can be increased by exceeding social capital and/or human capital. Thus, the organizations have to pay attention to their social and human capital as both of variables are important resources of improvement for their role as zakat institutions.

\section{REFERENCES}

[1] Hafidhudin, Didin. 2008. Zakat untuk Kesejahteraan Bersama. Public Persentation, Jakarta

[2] Hassan, Abul. 2014. The Challenge in Poverty Alleviation: Role of Islamic Microfinance and Social Capital, Humanomics, 30(1): 76-90.

[3] Pasban, M., \& Nojedeh, S.H. 2016. A Review of the Role of Human Capital in the Organization. Procedia-social and behavioral sciences 230: 249-253

[4] Field, John. 2003. Modal Sosial. Bantul: Kreasi Wacana.

[5] Brigaitis, P. 2005. Religious Engagement and Social Capital in Islamic Context. Master of Arts Thesis. Texas: University of North Texas.

[6] Gaol, J.L. 2014. A to Z Human Capital Manajemen Sumber Daya Manusia: Konsep, Teori, dan Pengembangan dalam Konteks Organisasi Publik dan Bisnis. Jakarta: PT Grasindo.

[7] Robbins, S.P. 2002. Prinsip-Prinsip Perilaku Organisasi. Jakarta: Erlangga.

[8] Gibson, J.L. 1987. Organisasi dan Manajemen (Perilaku, Struktur, Proses). Jakarta: Penerbit Erlangga. organizations both internally and externally. By internally, we discover that the people in the organization carry out individual and group tasks effectively enough as well as the effectiveness level of external relationship with stakeholders.

In addition of using the two approaches that have been mentioned, we also use the criteria of effectiveness itself by 